\title{
Price Discounts and Fashion Involvement to Increase Online Impulsive Buying: Study Among Teenagers at Yogyakarta
}

\author{
Dwi Wahyu Pril Ranto*, Endang Hariningsih*, Wahyu Eko Prasetyanto*, \\ Debby Mulya Oktafiani*
}

\author{
*Sekolah Tinggi Ilmu Bisnis (STIB) Kumala Nusa, Yogyakarta, Indonesia \\ Email: dwiwahyuprilranto@gmail.com
}

\begin{abstract}
This study aims to examine the relationship between discount prices and fashion involvement with impulse buying. The self-administrated questionnaire was developed from the literature administered to 135 female teenagers in Yogyakarta. Multiple regression analysis was used to examine the relationship between discount prices and fashion involvement in impulse buying. The results showed a significant relationship between discount prices and price involvement with impulse buying among teenagers. This study provides valuable insights into teenage impulse buying behavior in an online setting, especially Shopee marketplace, with integrated price discounts and fashion involvement as the antecedent
\end{abstract}

Keywords: Price Discounts, Fashion Involvement, Online Impulsive Buying, Marketplace

\section{How to Cite:}

Ranto, D. W. P., Hariningsih, E., Prasetyanto, W. E. and Oktafiani, D. M., (2021). Price discounts and fashion involvement to increase online impulsive buying: study among teenager at Yogyakarta. International Journal of Business, Management and Economincs, 2(4). 239 - 250. DOI: https://doi.org/10.47747/ijbme.v2i4.408

\section{Introduction}

The online marketplace has experienced very rapid development. The growth of the online retail market shows that many new retailers are planning to participate in an online marketplace (Lo et al., 2016). Although the entry of online retailers into the marketplace will create much competition in each segment. Understanding consumer online behavior becomes crucial for online retailers, increasing their competitive advantage to increase profits.

In this era of accelerated growth in e-commerce, the expansion of cellular networks has changed marketing patterns and consumer behavior. Mobile devices enable marketers to give consumers the pleasure of shopping and offer promotional campaigns through various applications at any time. Thus, consumers can shop anywhere and anytime they want online. It results in impulsive buying behavior that causes consumers to be more frequent and buy 
Vol. 2. No. 4. November 2021

(Chen \& Yao, 2018). Study of Nelson state that eight out of ten consumers in supermarkets purchase a item unplanned and one of five consumers baskets, contain impulse of impulse product (Cheng et al., 2013). Impulse buying is a condition when a consumer experiences a sudden, strong, and persistent desire to buy something immediately. Impulse buying is related to positive emotions (hedonists, rewards, etc.) and negative emotions (bad mood, stress) (Youn \& Faber, 2000). Impulse buying is also related to reduced self-control (Vohs, K.D. and Faber, 2007), low self-esteem, can contradict long-term goals (save money) and produce satisfaction but also regret and guilt (Rook, 1987).

Madhavaram \& Laverie (2004) provide an argument for buying stimuli by displaying eyecatching big titles by providing information on price reductions. Lo et al., (2016) also said that the discount price is one of the stimuli of sales promotion to produce impulse buying. Park et al., (2006) revealing other stimuli in the form of fashion involvement, which is a form of positive emotion to produce impulse buying.

Palan et al., (2010) revealed that adolescents are learning to become consumers and learn to achieve autonomy so that it is a specialized market segment because of their spending abilities. For teenagers, shopping is a form of entertainment, so they can be targeted by various marketing stimuli when they shop. People who are more vulnerable to emotional or affective state experiences will make impulsive buying faster (Dholakia, 2000). Muratore (2016) said that adolescents have the characteristics of a financial budget that does not bear fixed costs (house rent, tax fees, electricity, etc.) or routine variable living costs such as food, which are characteristic of the adult age group. Therefore, impulse buying in adolescence is an issue that requires further understanding of this phenomenon.

More specifically, this study studies the impulsive buying behavior among adolescents with influencing factors related to discounts and fashion involvement. Muratore (2016) revealed that impulsive buying and price stimuli are interrelated constructs. Whereas fashion-oriented impulse buying is strongly related to fashion involvement (Park et al., 2006). A study conducted by Han et al, (1991) expressed that fashion involvement can encourage fashionoriented impulse buying by providing sensory cues or experience of fashion products. Nevertheless, there is still no research that combines these two stimuli in one study for the context of phenomena among adolescents.

The paper was organized by revealing the literature review on impulsive buying, price discounts, fashion involvement, discussion, managerial and theoretical implications, and further research suggestions.

\section{Literature Review}

\subsection{Price Discount}

Price discount is one strategy that companies can use to compete in the future and maintain the store's image and form a positive image in the minds of consumers (Noor, 2020). Price discounts are not only helpful in attracting consumers but can also increase the number of company consumers. The increasing number of consumers certainly provides benefits for the company. This is the target of every company, which has made the company exist for a long time.

The company gives a discount price in a certain period and increases the sale of a product $(\mathrm{Xu}$ $\&$ Huang, 2014). Discount price can be offered as a reduction in terms of the percentage of the original price. Discounts are an extra incentive for consumers to take action or pay attention to the products offered. In other words, the size of the discount can encourage

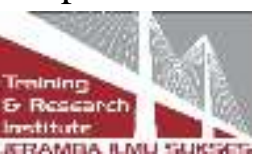


consumers to make a purchase. As has also been described by (Chen et al., 2012), a price Discount is a price reduction from the price list set by business people in a certain period. Price discounts can be offered as a reduction in the percentage of the original price, and there is also the use of Price Discounts for various product categories (Gauri et al., 2017).

In another definition, it is explained by (Waani \& Alfa Tumbuan, 2015) that a Price Discount is a price reduction from the price that the company has set within a certain period. In determining the discount price, business actors must have a strategy so that the discount provided is not detrimental and can attract buyers and passers-by (Waani \& Alfa Tumbuan, 2015). To support the Price Discount is an indoor product planning activity to influence potential consumers to buy the products being sold. Product arrangement must be considered, starting from arrangement based on type, color, brand, and strategic location, to create a consumer desire to buy. This is what needs to be considered for the success of the pricecutting strategy.

\subsection{Fashion involvement}

Involvement is the motivation generated by a particular stimulus or situation and is shown through appearance characteristics (Ghouri, 2014). Involvement is a motivational state that drives and directs consumers' cognitive processes and behavior when they make decisions. If involvement with a product is high, consumers will experience more robust responses such as strong emotions and feelings.

In marketing, fashion involvement refers to an interest in a fashion product category (such as clothing). Fashion involvement is used to predict behavioral variables related to clothing products, purchasing behavior, and consumer characteristics (Gunawan \& Sitinjak, 2018). According to (Ghouri, 2014) fashion involvement in clothing is closely related to personal characteristics, affecting consumer confidence in purchasing decisions.

Fashion involvement is the level of consumer consumption of clothing needs related to interactions between individuals as a social activity (Setyawati et al., 2018). Shopping is an activity that is often done by people, both young and old, to support their appearance or as an identity and is related to fashion. While fashion is an inseparable part of daily appearance and lifestyle; besides that, fashion can also be a small window about one's self for others (Andani \& Wahyono, 2018). Fashion involvement has a high correlation with impulsive buying behavior, so that consumers will purchase clothing impulsively with the latest models and designs (Kopral \& Çalik, 2015). Also, the involvement of the model can affect a person's positive emotions.

\subsection{Impulsive buying}

Impulse buying is an essential aspect of consumer behavior and a vital concept for retailers (Wahyudi, 2017). Consumers often make a purchase decision without a prior plan, where the purchase is made spontaneously because consumers are interested in the existence of price discounts and sales promotions. As well as the presentation of attractive goods, thereby generating consumer interest to buy.

Impulsive buying is a spontaneous decision that occurs suddenly and immediately before purchasing a product or service (Setyawati et al., 2018). Impulsive purchases can also be explained as purchases that occur when consumers see a particular product or brand, then become interested in getting it, and usually because of the new stimuli from the store (Suhud \& Herstanti, 2017; Lo et al., 2016). Impulsive or unplanned purchases are other forms of consumer purchasing patterns; according to the term, the purchase is not specific (Ahmad,

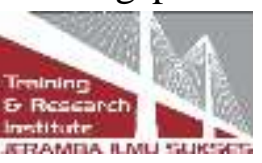


Vol. 2. No. 4. November 2021

2011). Two factors can influence impulse buying behavior, namely, internal and external factors. According to (Xu \& Huang, 2014), the interior elements of impulse buying behavior are the internal cues of consumers and the personality characteristics of consumers, where the inner impulse buying impulses refer to stimuli that are controlled and carried out by consumers themselves. Internal stimulation in this study is fashion involvement.

Impulsive buying intentions represent behavioral intentions, and impulsive traits represent traits. Chen \& Wang (2016) considers impulse buying as, and decision making is done immediately. Consumers with this trait have more frequent and intensive impulse buying intentions. Consumers like this make decisions using unplanned thinking, tend to be careless, often followed by inner emotional situations. Consumers with high impulsivity have more impulse buying intentions than those with low impulsivity. This type of consumer is weakwilled. Compared to consumers with low impulsivity. Consumers with high impulsivity can easily relate external information to internal emotions and ultimately lead to impulse buying (Wahyudi, 2017). Therefore, this study assumes that high-impulsivity consumers have more purchase intentions than low-impulsivity consumers in an online context.

\subsection{The effect of a price discount and Fashion Involvement on impulsive purchases}

One indicator of promotion is the price discount (Lo et al., 2016). The higher the level of publicity, the higher the impulse buying decision. This statement is supported by research conducted by (Xu \& Huang, 2014), which states that giving discounts has a positive and significant effect on impulsive buying variables. The same result is also explained by (Gauri et al., 2017) that providing price discounts has impacted impulsive buying variables. Suhud \& Herstanti, (2017) revealed that consumers buy products that were not planned due to attractive product descriptions, price discounts, and sales promotion girls created by the store environment. Based on the story above, in this study, the proposed hypothesis is:

H1: Price discount has a positive and significant influence on impulsive purchases

Fashion Involvement is the level of interest that is manifested from one's involvement in various matters in fashion or fashionable clothing. Fashion involvement is the level of consumer consumption of clothing needs, which are seen as related to interactions between individuals as a social activity (Sundström et al., 2019). Based on research conducted by (Andani \& Wahyono, 2018), fashion involvement has a significant influence on impulsive purchases with a total impact of $60 \%$, and fashion involvement has the most considerable effect on impulsive purchases. The same result is also explained by (Kopral \& Çalik, 2015; Liang, 2012), demonstrating that Fashion involvement has a positive and significant influence on impulsive purchases. Based on the description above, in this study, the proposed hypotheses are:

$\mathrm{H}$ 2: Fashion involvement has a positive and significant impact on impulsive purchases

\section{Research Method}

\subsection{Data}

This study aims to examine the relationship between discount prices and fashion involvement in impulse buying. This study uses quantitative methods. This method is very useful in understanding the relationship between variables. 
Vol. 2. No. 4. November 2021

Sampling in this study used convenience sampling with 135 respondents. The study population was female teenagers (aged 17-27 years) who live in Yogyakarta, who make purchases at the Shopee marketplace. Samples taken are those who made purchases at least 2 times during the last three months.

Price Discounts are interpreted as a reduction in the price that must be paid for certain products, which apply for a certain period (Waani \& Alfa Tumbuan, 2015). Indicators used to measure Price Discounts are; frequency of giving discounts, types of discounts, and the number of discounts provided (Kotler \& Armstrong, 2016). Fashion involvement is defined as individual perceptions and awareness related to clothing (Jun et al., 2010). Furthermore, the factors that influence fashion are 1) product involvement, (2) purchase decision involvement, (3) consumption involvement, (4) advertising involvement (O, Cass, 2000). According to Maymand and Ahmadinejad (2011) Impulsive Buying, impulsive buying is a complex, spontaneous, and sudden behavior in a speedy decision-making process, ignoring rationality and accuracy about the details and choices. Indicators to measure impulsive purchases are (1) being unintended or unwanted, (2) being unreflective, and (3) spontaneous or sudden (Jones et al., 2003). All Variable measurements using seven adjective bipolar scales.

\subsection{Multiple Linear Regression Analysis}

Data analysis in this study used multiple regression analysis. According to (Hair et al., 2019), Multiple regression analysis describes the relationship between dependent variables and more than one independent variable. Regression equation in this study:

$\mathrm{Y}=\mathrm{a}+\mathrm{b}_{1} \mathrm{X}_{1}+\mathrm{b}_{2} \mathrm{X}_{2}+\mathrm{e}$

Information:

$\mathrm{Y} \quad=$ impulse buying

$\mathrm{X}_{1}=$ discount prices

$\mathrm{X}_{2} \quad=$ fashion involvement

a $\quad=$ constant value

$\mathrm{b} 1, \mathrm{~b} 2=$ the coefficient number of each variable $\mathrm{X}$

e $\quad=$ error

\subsection{Simultaneous Testing (Test F)}

Simultaneous regression analysis (Test F) was conducted to prove the research hypothesis the significant effect of the independent research variables together on the dependent variable.

The testing criteria are as follows:

Ho is accepted: sig F $>0.05$ and $\mathrm{F}$ count $<\mathrm{F}$ table.

Ho is rejected: $\operatorname{sig} \mathrm{F} \leq 0.05$ and $\mathrm{F}$ count $\geq \mathrm{F}$ table.

Ho: There is no effect of discount prices and fashion involvement simultaneous against impulse buying. 
Vol. 2. No. 4. November 2021

Ha: There are effects of discount prices and fashion involvement simultaneous against impulse buying.

\subsection{Partial Testing (T Test)}

The regression analysis of the partial test of each independent variable on the dependent variable can be explained by using the t test. According to (Hair et al., 2019), the testing criteria are Hypothesis testing with $\mathrm{t}$ test, namely testing the hypothesis of variable $\mathrm{X}$ on variable Y partially or one by one. The test criteria are as follows:

Ho is accepted: sig $\mathrm{t}>0.05$ and $\mathrm{t}$ count $<\mathrm{t}$ table.

Ho is rejected: $\operatorname{sig} \mathrm{t} \leq 0.05$ and $\mathrm{t}$ count $\geq \mathrm{t}$ table.

Ho: There is no influence of discount prices and fashion involvement partially against impulse buying.

Ha: There are influences of discount prices and fashion involvement partially against impulse buying.

\section{Findings and Discussions}

\subsection{Instrument Testing Results}

The validity test in this study uses Pearson correlation. While to measure reliability is to look at the value of Cronbach's Alpha $(\alpha)$, where the instrument is declared reliable if the value of Cronbach's Alpha $(\alpha) \geq 0.6$.

Table 1. Validity and Reliability Test Results

\begin{tabular}{|c|c|c|c|c|}
\hline \multirow{2}{*}{ Variable } & \multirow{2}{*}{$\begin{array}{l}\text { Statement } \\
\text { Items }\end{array}$} & \multicolumn{2}{|c|}{ Validity } & \multirow{2}{*}{$\begin{array}{c}\text { Cronbach's } \\
\text { Alpha }\end{array}$} \\
\hline & & $r_{\text {value }}$ & $r_{\text {table }}$ & \\
\hline Price & X1.1 & 0.799 & 0.1427 & 0,893 \\
\hline \multirow[t]{9}{*}{ Discount } & $\mathrm{X} 1.2$ & 0.753 & & \\
\hline & $\mathrm{X} 1.3$ & 0.771 & & \\
\hline & X1.4 & 0.787 & & \\
\hline & $X 1.5$ & 0.720 & & \\
\hline & X1.6 & 0.754 & & \\
\hline & X1.7 & 0.649 & & \\
\hline & $\mathrm{X} 1.8$ & 0.621 & & \\
\hline & X1.9 & 0.748 & & \\
\hline & X1.10 & 0.554 & & \\
\hline Fashion & $\mathrm{X} 2.1$ & 0.699 & 0.1427 & 0,911 \\
\hline \multirow[t]{9}{*}{ Involvement } & $\mathrm{X} 2.2$ & 0.689 & & \\
\hline & $\mathrm{X} 2.3$ & 0.636 & & \\
\hline & $\mathrm{X} 2.4$ & 0.814 & & \\
\hline & $\mathrm{X} 2.5$ & 0.690 & & \\
\hline & $\mathrm{X} 2.6$ & 0.784 & & \\
\hline & $\mathrm{X} 2.7$ & 0.767 & & \\
\hline & $\mathrm{X} 2.8$ & 0.800 & & \\
\hline & X2.9 & 0.776 & & \\
\hline & $\mathrm{X} 2.10$ & 0.814 & & \\
\hline
\end{tabular}


Vol. 2. No. 4. November 2021

\begin{tabular}{lllll}
\hline Impulsive & Y.1 & 0.595 & 0.1427 & 0,879 \\
Buying & Y.2 & 0.775 & & \\
& Y.3 & 0.534 & & \\
& Y.4 & 0.785 & & \\
& Y.5 & 0.807 & \\
& Y.6 & 0.742 & \\
& Y.7 & 0.623 & \\
& Y.8 & 0.827 & \\
\hline
\end{tabular}

The table above shows that the statement items of all variables are declared valid because $r$ value is greater than $\mathrm{r}$ table. In addition, all variables are also stated to be reliable because Cronbach's Alpha is greater than 0.6.

\subsection{Hypothesis testing}

Hypothesis testing is done using multiple linear regression. The results of multiple linear regression tests can be seen in the following table:

Table 2 Results of Multiple Linear Regression Analysis

\begin{tabular}{|l|c|c|c|c|c|}
\hline \multirow{2}{*}{ Variabel } & \multicolumn{2}{|c|}{$\begin{array}{c}\text { Unstandardized } \\
\text { Coefficients }\end{array}$} & $\begin{array}{c}\text { Standardized } \\
\text { Coefficients }\end{array}$ & $\mathrm{t}$ & \\
\cline { 2 - 6 } & $\mathrm{B}$ & $\begin{array}{c}\text { Std. } \\
\text { Error }\end{array}$ & Beta & & \multirow{2}{*}{ Sig. } \\
\hline (Constant) & 1.470 & 0.842 & & 1.741 & 0.082 \\
\hline Price Discount $\left(\mathrm{X}_{1}\right)$ & 1.177 & 0.030 & 0.864 & 24.089 & 0.000 \\
\hline Fashion Involvement $\left(\mathrm{X}_{2}\right)$ & 0.132 & 0.042 & 0.205 & 5.130 & 0.000 \\
\hline F-Hitung & \multicolumn{7}{|c|}{246,073} \\
\hline Sig. F & \multicolumn{7}{|c|}{0,000} \\
\hline
\end{tabular}

$\mathrm{t}_{\text {table }}=0.67635$

Based on the results of the multiple regression model testing, which states the effect of price discount and fashion involvement on impulsive buying, it can be expressed by the following mathematical formula:

$$
\mathrm{Y}=1.470+1.177 \mathrm{X}_{1}+0.132 \mathrm{X}_{2}
$$

Based on Table 2 above, it can be summarized that hypothesis 1 is accepted ( $t$ value is 24.089 and p-value is 0.000). That means that Price Discount has a significant and positive effect on Impulsive Buying. Furthermore, hypothesis 2 also supported ( $\mathrm{t}$ value is 5.130 and $\mathrm{p}$-value 0.00 ). That means that Fashion Involvement significantly and positively influences Impulsive Buying. According to the coefficient in multiple regression, we can conclude that price discount and fashion involvement have positive value. This means that the more discounted prices and the higher the involvement of fashion, the more impulse buying behavior increases.

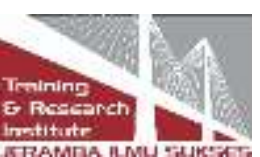


Vol. 2. No. 4. November 2021

While based on Table 2, the results of the F test above, the F test statistical value is 246,073 and a significance value of 0.000 . So that the significance value of 0.000 is less than 0.05 . Thus it can be concluded that the independent variables price discount (X1) and fashion involvement (X2) together have significant and positive effects against the impulsive buying (Y). this means that the better the price discount and fashion involvement will improve impulsive buying.

\subsection{Discussions}

the hypothesis test results above show that price discount significantly and positively influences impulsive buying. This means that the more frequent or high price discounts will further enhance the occurrence of impulsive purchases. The findings of this study are in line with the results of previous studies (Lo et al., 2016; (Xu \& Huang, 2014) (Gauri et al., 2017)(Suhud \& Herstanti, 2017). This further confirms that discounted prices can immediately provoke purchase intentions (even purchasing decisions) (Mohammad Mahmoudi Maymand \& Ahmadinejad, 2012). These spontaneous and unplanned purchases are the main characteristics of impulsive buying (Jones et al., 2003). If they first wanted to look at products in an e-catalog of an online store, they spontaneously decided to buy the product once they saw exciting information, which is in the form of a discount. This discount is an external factor that causes Impulse Buying as intended by (Xu \& Huang, 2014). This finding can be important information for online sellers who display their products in the Shopee market, especially for products intended for young women. By giving a variety of discounts on the products they sell, it is possible to enhance the possibility of impulsive buying.

Fashion involvement also found a significant and positive impact on impulsive buying( $t$ value $=5,130$ and significance level 0,000 ). That means that $\mathrm{H} 2$ is supported. This means that the higher the fashion involvement of the buyers will enhance the possibility of impulse purchases. These findings are consistent with an earlier study (Park et al., 2006) that found fashion involvement having the most significant effect on impulse buying. The findings of this study are in line with the results of previous studies (Sundström et al., 2019) (Andani \& Wahyono, 2018); (Kopral \& Çalik, 2015); (Liang, 2012). This is an important note for sellers who sell their products online, primarily through the Shopee marketplace. To increase sales through an impulsive buying process, sellers must create and increase fashion involvement from consumers.

Fashion involvement depends on how important clothes are to someone. Thus, efforts to increase fashion involvement can be focused on efforts to deliver information that gives an emotional touch to the prospective consumer about how important and attractive the product offered to her. Consumers who have a high level of involvement in a product tend to spend more time in the store and interact with the product to be bought (Sigit et al., 2016) (Sigit et al., 2016). High involvement of the fashion reflects the interaction and experience towards fashion products. The involvement of fashion will build positive emotions and makes consumers tend to shop hedonistically. This is an important note for sellers who sell their products online, especially through the Shopee market place. To increase sales through an impulsive buying process, sellers must be able to create and increase fashion involvement from consumers. 
Vol. 2. No. 4. November 2021

\section{Conclusion}

The study examined the relationship between price discounts and fashion involvement to the impulse behavior of teenagers in Yogyakarta. Overall, the result supports the concept of the impulse buying model. Based on these results can be made some theoretical and practical implications. Related to price discounts, the results of this study can provide advice so that sellers in shopee market share can provide a variety of discount offers, especially for relatively cheap products. This is done because this type of product has a price-sensitive market segment, so discounts are expected to improve impulse behavior. However, discounted prices should be done carefully. (Raghubir \& Corfman, 1999) discovered that promotional tactics can be detrimental to store owners, as buyers may believe decreased pricing indicates poor product quality. When the discount is too significant, people lose interest in making a purchase. Additionally, conducting promotional efforts frequently lowers its attraction, leading consumers to doubt the product's quality (Bell et al., 1999).

Implications for the owner/manager of fashion stores in Shopee related to the support of fashion involvement is needed attention to the emotional side of consumers. Shopee is a marketplace that identifies with female consumers. It is, therefore, suitable for the sale of fashion products whose tendencies are favored by women. Fashion involvement depends on how important clothes are to someone. Thus, efforts to increase fashion involvement can be focused on efforts to deliver information that gives an emotional touch to the prospective consumer about how important and attractive the product offered to her. Owners/sellers of fashion products in Shoppe need to improve their Shopee sales account management capabilities in order to be able to create an attractive description of their fashion products along with product usage videos, in addition to increasing the ability to understand products and provide advice to buyers regarding certain fashion styles. The research is on the Shopee teenager consumer marketplace, which is identical to female consumers. Future studies can explore other marketplaces to emphasize and expand the study of price discounts and fashion involvement.

This research focuses on a teenager who lives in Yogyakarta. Future research can be developed in various cities with more diverse characteristics to obtain a more specific and complete picture of the phenomena examined in this research. This study selects respondents in the teenage category of about age 17-27 years. Future studies may be developed into an age range above that age range to see the extent of the effects of this study on a more mature age range.

\section{References}

Ahmad, T. (2011). The impulse buying behavior of consumes for the FMCG products in Jodhpur. Australian Journal of Basic and Applied Sciences, 5(11), 1704-1710.

Andani, K., \& Wahyono, W. (2018). Influence of Sales Promotion, Hedonic Shopping Motivation and Fashion Involvement Toward Impulse Buying through a Positive Emotion. Management Analysis Journal, 7(4), 448-457. https://doi.org/10.15294/maj.v7i4.24105

Bell, D. R., Chiang, J., \& Padmanabhan, V. (1999). The decomposition of promotional response: An empirical generalization. Marketing Science, 18(4), 504-526. https://doi.org/10.1287/mksc.18.4.504 
Vol. 2. No. 4. November 2021

Chen, C. C., \& Yao, J. Y. (2018). What drives impulse buying behaviors in a mobile auction? The perspective of the Stimulus-Organism-Response model. Telematics and Informatics, 35(5), 1249-1262. https://doi.org/10.1016/j.tele.2018.02.007

Chen, Marmorstein, H., Tsiros, M., \& Rao, A. R. (2012). When More Is Less : The Impact of Base Value Neglect on Consumer Price Discounts. 76(July), 64-77.

Chen, Y.-F., \& Wang, R.-Y. (2016). Are humans rational? Exploring factors influencing impulse buying intention and continuous impulse buying intention. Journal of Consumer Behaviour, 15(December), 186-197. https://doi.org/10.1002/cb.1563

Cheng, Y. H., Chuang, S. C., Wang, S. M., \& Kuo, S. Y. (2013). The Effect of Companion's Gender on Impulsive Purchasing: The Moderating Factor of Cohesiveness and Susceptibility to Interpersonal Influence. Journal of Applied Social Psychology, 43(1), 227-236. https://doi.org/10.1111/j.1559-1816.2012.00977.x

Dholakia, U. M. (2000). Temptation and resistance: An integrated model of consumption impulse formation and enactment. Psychology and Marketing, 17(11), 955-982. https://doi.org/10.1002/1520-6793(200011)17:11<955::AID-MAR3>3.0.CO;2-J

Gauri, D. K., Ratchford, B., Pancras, J., \& Talukdar, D. (2017). An Empirical Analysis of the Impact of Promotional Discounts on Store Performance. Journal of Retailing, 93(3), 283-303. https://doi.org/10.1016/j.jretai.2017.06.001

Ghouri, A. (2014). Measuring the Mediating Impact of Hedonic Consumption on Fashion Involvement And Impulse Buying Behavior. Indian Journal of Commerce \& Management Studies, 5(3), 50-57.

Gunawan, G. T., \& Sitinjak, T. (2018). Pengaruh Keterlibatan Fashion Dan Gaya Hidup Berbelanja Terhadap Pembelian Impulsif (Studi Terhadap Remaja Dan Pemuda Dki Jakarta). Jurnal Manajemen, Vol.7(No.2), 109-123.

Hair, J. F., Black, W. C., Babin, B. J., Anderson, R. E., Black, W. C., \& Anderson, R. E. (2019). Multivariate Data Analysis (Eighth). Cengage. https://doi.org/10.1002/9781119409137.ch4

Han, Y.K., Morgan, G.A., Kotsiopulos, A. and Kang-Park, J. (1991). buying behaviour of apparel purchasers. Clothing and Textiles Research Journal, 9(3), 15-21.

Jones, M. A., Reynolds, K. E., Weun, S., \& Beatty, S. E. (2003). The product-specific nature of impulse buying tendency. Journal of Business Research, 56(7), 505-511. https://doi.org/10.1016/S0148-2963(01)00250-8

Jun, D.-G., Choo, H.-J., \& Kim, H.-S. (2010). A Study on the Clothing Involvement, Fashion Innovativeness, Impulsive Buying, and Brand Loyalty of Male University Students. In Journal of the Korean Society of Clothing and Textiles (Vol. 34, Issue 3, pp. 424-436). https://doi.org/10.5850/jksct.2010.34.3.424

Kopral, C. C., \& Çalik, N. (2015). Hedonic Consumption Characteristics Related to Products and Services where Fashion Involvement Plays an Important Role, A Field Study from Eskisehir, Turkey. International Journal of Social Sciences, IV(1), 14-39. https://doi.org/10.20472/ss2015.4.1.002

Liang, Y.-P. (2012). The Relationship between Consumer Product Involvement, Product Knowledge and Impulsive Buying Behavior. Procedia - Social and Behavioral Sciences, 
Vol. 2. No. 4. November 2021

57(03), 325-330. https://doi.org/10.1016/j.sbspro.2012.09.1193

Lo, L. Y. S., Lin, S. W., \& Hsu, L. Y. (2016). Motivation for online impulse buying: A twofactor theory perspective. International Journal of Information Management, 36(5), 759 772. https://doi.org/10.1016/j.ijinfomgt.2016.04.012

Madhavaram, S. R., \& Laverie, D. A. (2004). Association For Consumer Research Exploring Impulse Purchasing on the Internet Exploring Impulse Purchasing on the Internet. 31(31), 59-66. http://www.acrwebsite.org/volumes/8849/volumes/v31/NA-31

Mohammad Mahmoudi Maymand, \& Ahmadinejad, M. (2012). Impulse buying: the role of store environmental stimulation and situational factors (An empirical investigation). African Journal of Business Management, 5(34). https://doi.org/10.5897/ajbm11.2112

Muratore, I. (2016). Teens as impulsive buyers: what is the role of price? International Journal of Retail and Distribution Management, 44(11), 1166-1180. https://doi.org/10.1108/IJRDM-08-2015-0120

Noor, Z. Z. (2020). the Effect of Price Discount and in-Store Display on Impulse Buying. Sosiohumaniora: Jurnal Ilmu-Ilmu Sosial Dan Humaniora, 22(2), 133-139. https://doi.org/10.24198/sosiohumaniora.v22i2.26720

O, Cass, A. O. (2000). An assessment of consumers product, purchase decision, advertising and consumption involvement in fashion clothing. Journal of Economic Psychology, 21.

Palan, K. M., Gentina, E., \& Muratore, I. (2010). Adolescent consumption autonomy: A crosscultural examination. Journal of Business Research, 63(12), 1342-1348. https://doi.org/10.1016/j.jbusres.2010.01.001

Park, E. J., Kim, E. Y., \& Forney, J. C. (2006). A structural model of fashion-oriented impulse buying behavior. Journal of Fashion Marketing and Management, 10(4), 433-446. https://doi.org/10.1108/13612020610701965

Raghubir, P., \& Corfman, K. I. M. (1999). When Do Price Promotions Affect Pretrial Brand Evaluations? Author $(s)$ : Priya Raghubir and Kim Corfman Published by: American Marketing Association Stable URL: http://www.jstor.org/stable/3152094 Accessed: 0503-2016 20: 03 UTC Your use of the JSTO. 36(2), 211-222.

Rook, D. W. (1987). The buying impulse. Journal of Consumer Research, 14(22), 305-313.

Setyawati, S. M., Sumarsono, \& Praditya, I. (2018). The Influence of Fashion Involvement, Hedonic Consumption, and Visual Merchandising on Impulse Buying with Positive Emotion as Mediation Variables. Journal of Accounting Management and Economics, 20(1), 37-47.

Sigit, R., Lukito, H., \& Tulipa, D. (2016). Impulse Buying Behavior On Consumer Retail Fashion In Surabaya - Indonesia. IJABER, 14(11), 8071-8086.

Suhud, U., \& Herstanti, G. (2017). Investigating the impulse buying of young online shoppers. Advanced Science Letters, 23(1), 660-664. https://doi.org/10.1166/as1.2017.7290

Sundström, M., Hjelm-Lidholm, S., \& Radon, A. (2019). Clicking the boredom away Exploring impulse fashion buying behavior online. Journal of Retailing and Consumer Services, 47(March 2018), 150-156. https://doi.org/10.1016/j.jretconser.2018.11.006

Vohs, K.D. and Faber, R. J. (2007). Spent resources: self-regulatory resource availability affects impulse buying. Journal of Consumer Reaserch, 33(4), 537-547.

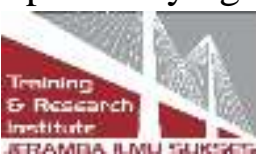


Vol. 2. No. 4. November 2021

Waani, R. C. T., \& Alfa Tumbuan, W. J. F. (2015). the Influence of Price Discount, Bonus Pack, and in-Store Display on Impulse Buying Decision in Hypermart Kairagi Manado. F.A. Tumbuan. The Influence of Price ... Jurnal EMBA, 33(4213), 420-428.

Wahyudi, S. (2017). Pengaruh Price Discount Terhadap Impulse Buying. Jurnal Valuta, 2(2), $1-10$.

Xu, Y., \& Huang, J. S. (2014). Effects of price discounts and bonus packs on online impulse buying. Social Behavior and Personality, 42(8), 1293-1302. https://doi.org/10.2224/sbp.2014.42.8.1293

Youn, S., \& Faber, R. J. (2000). Impulse buying: its relation to personality traits and cues. Advances in Consumer Research, 27(2), 179-186.

\section{Copyrights}

Copyright for this article is retained by the author(s), with first publication rights granted to the journal.

This is an open-access article distributed under the terms and conditions of the Creative Commons Attribution license (http://creativecommons.org/licenses/by/4.0/ 